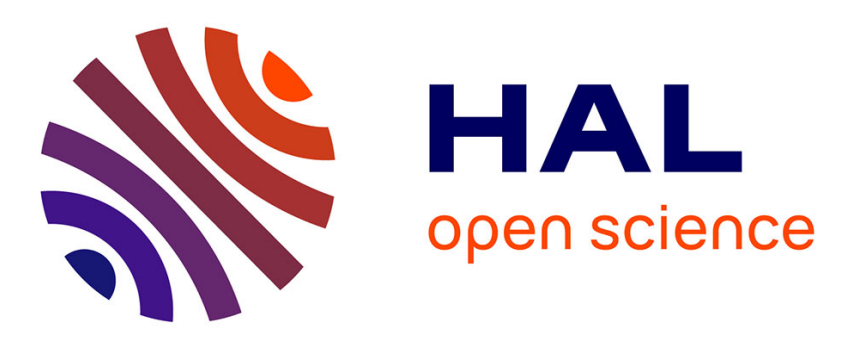

\title{
Fe/S-Catalyzed Synthesis of 2-Benzoylbenzoxazoles and 2-Quinolylbenzoxazoles via Redox Condensation of o-Nitrophenols with Acetophenones and Methylquinolines
}

Le Anh Nguyen, Thi Thu Tram Nguyen, Quoc Anh Ngo, Thanh Binh Nguyen

\section{- To cite this version:}

Le Anh Nguyen, Thi Thu Tram Nguyen, Quoc Anh Ngo, Thanh Binh Nguyen. Fe/S-Catalyzed Synthesis of 2-Benzoylbenzoxazoles and 2-Quinolylbenzoxazoles via Redox Condensation of o-Nitrophenols with Acetophenones and Methylquinolines. Organic \& Biomolecular Chemistry, 2021, 19 (27), pp.6015-6020. 10.1039/D1OB00976A . hal-03325817

\section{HAL Id: hal-03325817 \\ https://hal.science/hal-03325817}

Submitted on 25 Aug 2021

HAL is a multi-disciplinary open access archive for the deposit and dissemination of scientific research documents, whether they are published or not. The documents may come from teaching and research institutions in France or abroad, or from public or private research centers.
L'archive ouverte pluridisciplinaire HAL, est destinée au dépôt et à la diffusion de documents scientifiques de niveau recherche, publiés ou non, émanant des établissements d'enseignement et de recherche français ou étrangers, des laboratoires publics ou privés. 


\section{Journal Name}

\section{COMMUNICATION}

\section{Fe/S-Catalyzed Synthesis of 2-Benzoylbenzoxazoles and 2- Quinolylbenzoxazoles via Redox Condensation of $o$-Nitrophenols with Acetophenones and Methylquinolines}

Received 00th January 20xx Accepted 00th January 20xx

DOI: $10.1039 / x 0 x \times 00000 x$

www.rsc.org/

\author{
Le Anh Nguyen, ${ }^{b, c, \ddagger}$ Thi Thu Tram Nguyen, ${ }^{\mathrm{d}, \ddagger}$ Quoc Anh Ngo, ${ }^{* b, c}$ and Thanh Binh Nguyen*a
}

$\mathrm{Fe} / \mathrm{S}$ catalyst generated in situ from $\mathrm{FeCl}_{2} \bullet 4 \mathrm{H}_{2} \mathrm{O}$ and elemental sulfur $\mathrm{S}_{8}$ in the presence of a tertiary amine as a base was found to catalyze efficiently a $6 \mathrm{e}^{-}$redox condensation of $o$-nitrophenols with acetophenones and methylquinolines. The condensed products 2 benzoyl benzoxazoles and 2-quinolyl benzoxazoles were obtained in reasonable yields with water as the only byproduct at temperature as low as $80^{\circ} \mathrm{C}$.

2-Benzoylbenzoxazoles ${ }^{1}$ and 2-quinolylbenzoxazoles represent versatile building blocks for building diverse molecular scaffolds, including bioactive molecules I-III ${ }^{2}$ and fluorescence probes IV and $\mathbf{V} .^{3}$ In fact, I and III were identified to be an antiproliferative agent, ${ }^{3 \mathrm{c}}$ while II was found as a potent inhibitor of fatty acid amide hydrolase (Scheme 1). ${ }^{2 a}$

Consequently, a number of synthetic methods have been developed. Benzoxazole functionalization allows access to complex derivatives from simpler starting materials such as $2 \mathrm{H}$ benzoxazoles, ${ }^{4}$ benzoxazoles 2 -substituted ${ }^{5}$ by suitable activating groups or 2-benzyl benzoxazoles. ${ }^{6}$ The benzoxazole ring could be created from 2-aminophenols via non redox condensation, ${ }^{7}$ oxidative coupling ${ }^{8}$ or cyclization ${ }^{9}$ reactions.

In parallel, a condensation between two starting materials proceeding with change in oxidation states and removal of small molecules, i.e. redox condensation, is an interesting strategy to benzoxazole cores. Beifuss suggested an original approach to 2benzoylbenzoxazole based on redox condensation of 0 nitrosophenols which act as oxidant components with 2bromoacetophenones as reducing components (Scheme 2). ${ }^{10}$

\footnotetext{
a. Institut de Chimie des Substances Naturelles, CNRS UPR 2301, Université ParisSud, Université Paris-Saclay, 1, av de la Terrasse, 91198 Gif-sur-Yvette France. Email: thanh-binh.nguyen@cnrs.fr

b. Institute of Chemistry, Vietnam Academy of Science and Technology, 18 Hoang Quoc Viet, Cau Giay, Hanoi, Vietnam.Email:ngoqanh@ich.vast.vn

Graduate University of Science and Technology, Vietnam Academy of Science and Technology, 18 Hoang Quoc Viet, Cau Giay, Hanoi, Vietnam

d. Department of Chemistry, Faculty of Science, Can Tho University of Medicine and Pharmacy, Vietnam

† These authors contributed equally to this work.

Electronic Supplementary Information (ESI) available: details of any supplementary information available should be included here. See DOI: 10.1039/x0xx00000x
}

This base-promoted reaction proceeded without any added reducing or oxidizing agent. However, the main drawbacks of this approach are limited availability of both starting substrates, especially o-nitrosophenols along with lachrymatory nature of phenacyl bromides.<smiles>COc1cc(C(=O)c2nc3ccccc3o2)cc(OC)c1OC</smiles>

I, anti-proliferative

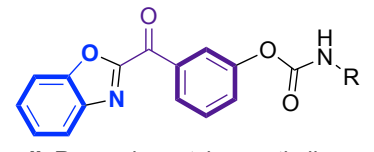

II, R = cyclopentyl, o-methylbenzyl inhibitor of fatty acid amide hydrolase<smiles>CN(C)CCCNc1nc2ccccc2nc1-c1nc2ccccc2o1</smiles>

III, anti-proliferative

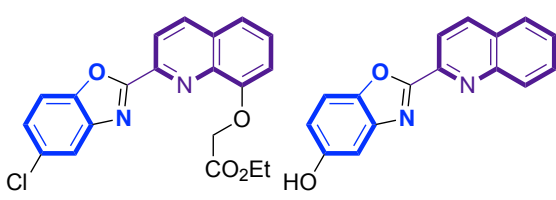

IV fluorescent probes $\mathbf{V}$
Scheme 1. 2-Benzoyl and 2-Quinolyl Benzoxazoles

In general, all known methods for the synthesis of 2benzoylbenzoxazole require substrates that are more or less functionalized with activating or protecting groups, the efficiency of the global processes in terms of atom-, step-, and redox- economies could be further improved. For example, while 2-aminophenols are the precursor of choice for most benzoxazoles, they are generally obtained by $6 \mathrm{e}^{-}$reduction of readily available $o$-nitrophenols 1 . In an ideal scenario, a synthesis of $\mathbf{3}$ via redox condensation with $\mathbf{1}$ as an oxidizing partner would involve acetophenones $\mathbf{2}$ as a reducing partner. Such a shortcut approach would produce two molecules of water as the only byproduct.

In living systems, the redox transformations are frequently orchestrated by the metalloenzymes. ${ }^{11}$ Among the most representative examples, iron-sulfur clusters, ubiquitous in cellular proteins, are best known for their involvement in a wide range of in the oxidation-reduction reactions. ${ }^{12}$

The last decades have seen a tremendous development in the understanding of the mechanism of these enzymes. ${ }^{13}$ However, 
their application in organic synthesis has so far not been adequately explored due to both structural and electronic complexity of these systems. Recently, the bioinspired Fe/Sbased catalytic systems were developed for the redox condensation between nitro groups with different reducing substituents. ${ }^{14,15}$ Using iron sources such as metallic iron or simple iron salts and elemental sulfur as the sulfur source for in situ formation of Fe-S catalytic species, we and others have succeeded in condensing aromatic nitro compounds with methylhetarenes, ${ }^{14 a}$ amines, ${ }^{14 b, c}$ phenylacetic acids, ${ }^{14 d}$ alcohol, ${ }^{14}$ e benzyl cyanides, ${ }^{14 f}$ dibenzyl disulfides ${ }^{15 a}$ and $p$ methylphenols, ${ }^{15 b-d}$ enabling the synthesis of a wide range of nitrogen heterocycles.

Beifuss method: $\mathrm{NO} / \mathrm{CH}_{2} 4 e^{-}$redox condensation

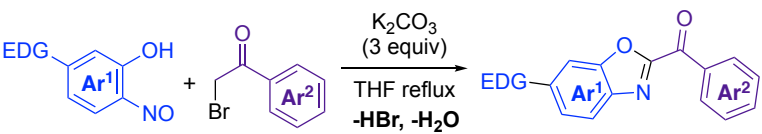

drawbacks: - limited availability of o-nitrosophenols (stabilized by a 5-EDG) - lachrymatory phenacyl bromides - use of base to remove $\mathrm{HBr}$

Our method: $\mathrm{NO}_{2} / \mathrm{CH}_{3}$ 6e- redox condensation using bioinspired $\mathrm{Fe} / \mathrm{S}$ catalyst

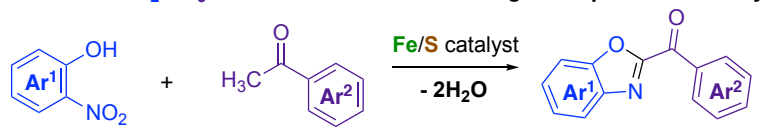

1

advantages + inexpensive, readily available substrates

+ userfriendly substrates

+ water as the only byproduc

$+\mathrm{Fe} / \mathrm{S}$ catalyst from simple and inexpensive precursors
Fe/S clusters:

biological redox reactions

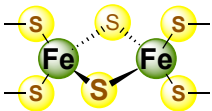

rhombic [2Fe-2S]

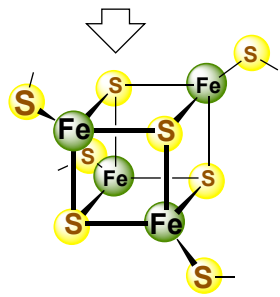

cubane $[4 \mathrm{Fe}-4 \mathrm{~S}]$

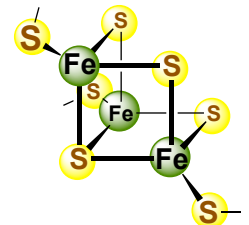

cubane-derived [3Fe-4S]
Scheme 2. Redox Condensation to Benzoxazoles 3

In continuing our work, we report here our extension to $6 \mathrm{e}^{-}$ redox condensation of $\mathbf{1}$ and $\mathbf{2}$ to $\mathbf{3}$.

At the outset of this study, we chose $o$-nitrophenol 1a and acetophenone $2 \mathrm{a}$ as the model substrates. Their reaction in the presence of $\mathrm{FeCl}_{2} .4 \mathrm{H}_{2} \mathrm{O}(10 \mathrm{~mol} \%)$ and sulfur ${ }^{16}(0.5 \mathrm{mmol}$ based on atomic sulfur) was found to provide the expected 2benzoylbenzoxazole 3aa in a moderate yield in the presence of $\mathrm{N}$-methylpiperidine (1 equiv) as a base at $80^{\circ} \mathrm{C}$ (entry 1 ). While other bases such as DIPEA, $\mathrm{NEt}_{3}$ or $\mathrm{NPr}_{3}$ were found to be efficient as an additive (entries $2-4$, respectivelive), no reaction was observed with weaker nitrogen bases such as $N$ methylmorpholine (entry 5) or pyridine (entry 6) or in the absence of a basic additive (entry 7). $\mathrm{FeCl}_{3} \bullet 6 \mathrm{H}_{2} \mathrm{O}$ also displayed a similar result (entry 8 ), which could be understood by the reversibility of the $\mathrm{Fe}^{2+} / \mathrm{Fe}^{3+}$ interconversion in the presence of both oxidizing and reducing agents. The reaction occurred even with lower iron or sulfur catalyst loading (entries 9-12) but was found to be totally inhibited in the absence of either iron salt or sulfur (entries 13-14). Interestingly, the reaction was found to proceed at temperature as low as $60{ }^{\circ} \mathrm{C}$ despite a low yield (entry 15). Lower yield was observed at a higher reaction temperature (entry 16), possibly due to loss of both starting materials by evaporation. Under the optimized condition of catalysts and base additive, we found that pyridine as a second additive was shown to be beneficial (entry 17 vs entry 9). Although further investigation is needed to understand the role of pyridine, this base could act as a stabilizing ligand for $\mathrm{Fe} / \mathrm{S}$ complex and thus enhance the catalytic activity.

Finally, for comparison purpose, $\mathrm{Co}(\mathrm{OAC})_{2} \bullet 4 \mathrm{H}_{2} \mathrm{O}$ and $\mathrm{Ni}(\mathrm{OAc})_{2} \bullet 4 \mathrm{H}_{2} \mathrm{O}$ were intendedly used in place of iron salt. While Co salt displayed a weak catalytic activity, Ni salt was shown to be completely inefficient, the reaction resulted in both unchanged starting materials.

Table 1. Screening of Redox Condensation Conditions

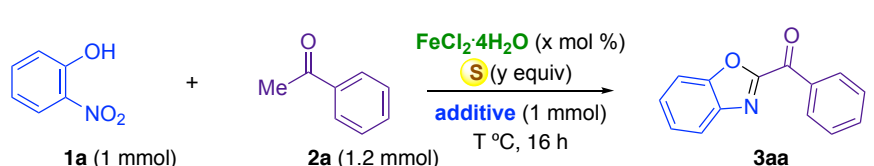

\begin{tabular}{cccccc}
\hline Entry $^{\mathrm{a}}$ & $\mathrm{x}$ & $\mathrm{y}$ & additive & $\mathrm{T}\left({ }^{\circ} \mathrm{C}\right)$ & ${\text { yield }(\%)^{\mathrm{b}}}^{\mathrm{n}}$ \\
\hline 1 & 10 & 1 & $N$-methylpiperidine & 80 & 50 \\
2 & 10 & 1 & DIPEA & 80 & 63 \\
3 & 10 & 1 & NEt $_{3}$ & 80 & 46 \\
4 & 10 & 1 & NPr $_{3}$ & 80 & 40 \\
5 & 10 & 1 & $N$-methylmorpholine & 80 & $0^{\mathrm{c}}$ \\
6 & 10 & 1 & pyridine & 80 & $0^{\mathrm{c}}$ \\
7 & 10 & 1 & - & 80 & $0^{\mathrm{c}}$ \\
$8^{\mathrm{d}}$ & 10 & 1 & DIPEA & 80 & 52 \\
9 & 5 & 1 & DIPEA & 80 & 67 \\
10 & 2 & 1 & DIPEA & 80 & 57 \\
11 & 1 & 1 & DIPEA & 80 & 45 \\
12 & 5 & 0.5 & DIPEA & 80 & 55 \\
13 & 0 & 1 & DIPEA & 80 & 0 \\
14 & 1 & 0 & DIPEA & 80 & 0 \\
15 & 5 & 1 & DIPEA & 60 & 28 \\
16 & 5 & 1 & DIPEA & 100 & 65 \\
17 & $\mathbf{5}$ & $\mathbf{1}$ & DIPEA:Pyridine & 80 & $\mathbf{7 2}$ \\
$18^{\mathrm{f}}$ & 5 & 1 & DIPEA:Pyridine & 80 & 27 \\
$19 \mathrm{~g}$ & 5 & 1 & DIPEA:Pyridine & 80 & $0^{\mathrm{c}}$ \\
& & & & &
\end{tabular}

a Reaction conditions: $o$-nitrophenol $1 \mathbf{a}(1 \mathrm{mmol})$, acetophenone $2 \mathrm{a}(1.2 \mathrm{mmol})$ $\mathrm{FeCl}_{2} \bullet 4 \mathrm{H}_{2} \mathrm{O}(\mathrm{x} \mathrm{mol} \%)$ sulfur (y mmol, $32 \mathrm{mg} / \mathrm{mmol}$ ), additive $(1 \mathrm{mmol}), 80^{\circ} \mathrm{C}, 16 \mathrm{~h}$. ${ }^{b}$ Isolated yield. c Determined by ${ }^{1} \mathrm{H}$ NMR of the crude mixture. ${ }^{d} \mathrm{FeCl}_{3} \bullet 6 \mathrm{H}_{2} \mathrm{O}$ was used in place of $\mathrm{FeCl}_{2} \bullet 4 \mathrm{H}_{2} \mathrm{O}$. e DIPEA ( $\left.1 \mathrm{mmol}\right)$, pyridine $(1 \mathrm{mmol})$. ${ }^{\mathrm{f}} \mathrm{Co}(\mathrm{OAc})_{2} \bullet 4 \mathrm{H}_{2} \mathrm{O}$ was used in place of $\mathrm{FeCl}_{2} \bullet 4 \mathrm{H}_{2} \mathrm{O}$. g $\mathrm{Ni}(\mathrm{OAC})_{2} \bullet 4 \mathrm{H}_{2} \mathrm{O}$ was used in place of $\mathrm{FeCl}_{2} \bullet 4 \mathrm{H}_{2} \mathrm{O}$.

Encouraged by this initial result, we have then explored the generality of the Fe/S-catalyzed redox condensation. Pleasingly, the optimized condition for the model reaction in Table 1, entry 17 , could be applied for the redox condensation of 22 different methyl ketones $\mathbf{2 b - 2} \mathbf{w}$ with o-nitrophenol $\mathbf{1 a}$. In all cases, the 2acylbenzoxazole derivatives $\mathbf{3 b}$-3aw were obtained in moderate to high yields (Scheme 3). Substituents such as methyl, methoxy, halogens were found to be suitable to deliver the expected products 3ab-3al in comparable yields to 
unsubstituted acetophenone $\mathbf{2 a}$. It should be noted that the reactions with sterically demanding ketone such as $\mathbf{2 c}$ or with sparingly soluble ketone $\mathbf{2 g}$ required heating at higher temperatures $\left(100{ }^{\circ} \mathrm{C}\right.$ and $90{ }^{\circ} \mathrm{C}$, respectively). We emphasized that ketone 3af, which was previously found to display antiproliferative property (compound I, Scheme 1) could be synthesized directly by our method.

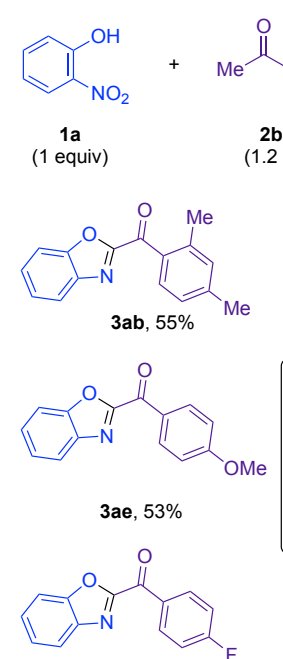

$$
\begin{gathered}
\mathrm{S} \text { (1 equiv) } \\
\underset{\mathrm{FeCl}_{2} \cdot 4 \mathrm{H}_{2} \mathrm{O}(5 \mathrm{~mol} \%)}{\mathrm{DIPEA}(1 \text { equiv) }} \\
\text { pyridine (1 equiv) } \\
80-100^{\circ} \mathrm{C}, 16 \mathrm{~h}
\end{gathered}
$$

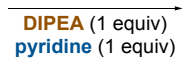

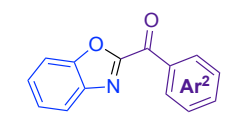

3ab-3aw

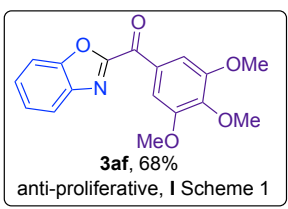

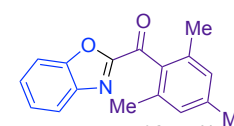

3ac, $100{ }^{\circ} \mathrm{C}, 58 \% \mathrm{M}$

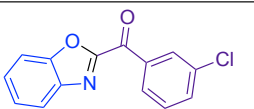

3ah, $62 \%$

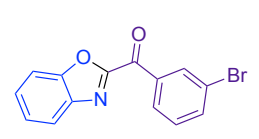

3ak, $55 \%$

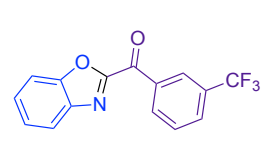

3an, $65 \%$

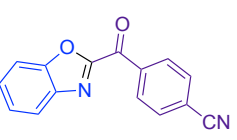

3aq, $62 \%$

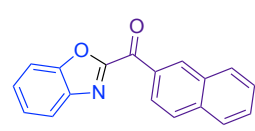

3at, $62 \%$

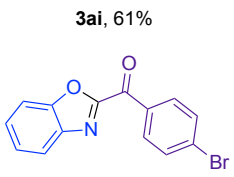

3al, $63 \%$

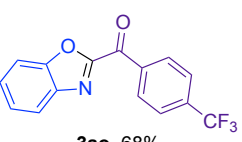

3ao, $68 \%$

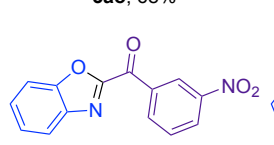

3ar, $54 \%$

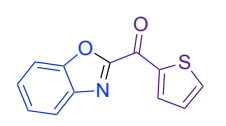

3au, $65 \%$

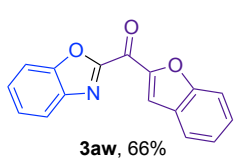

3aw, $66 \%$

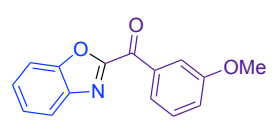

3ad, $55 \%$

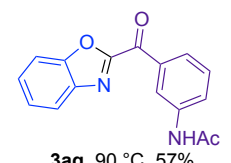

3ag, $90{ }^{\circ} \mathrm{C}, 57 \%$

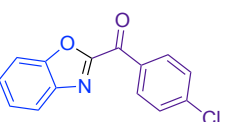

3aj, $53 \%$

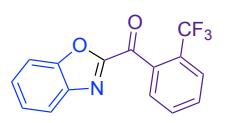

3am, $63 \%$

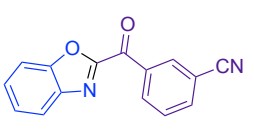

3ap, $65 \%$

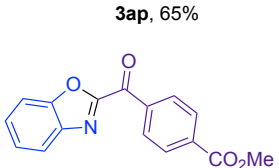

3as, $59 \%$

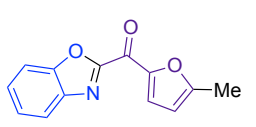

3av, $67 \%$

Scheme 3. Scope of Methyl Aryl Ketones 2

Ketones bearing electron withdrawing groups such as trifluoromethyl, $\mathrm{CN}, \mathrm{NO}_{2}$, methyl ester were also competent substrates. Acetyl derivatives of polyaromatic or heteroaromatic substrates such as 2-naphthyl $\mathbf{2 t}$, thiophene $\mathbf{2 u}$, furan $\mathbf{2 v}$ and benzofuran $\mathbf{2 w}$ exhibited similar reactivity, providing ketones 3at-3aw in reasonable yields.

Next, we focused our attention on the reactions of acetophenone $\mathbf{2 a}$ with different substituted $\boldsymbol{o}$-nitrophenols $\mathbf{1 b}$ 1g (Scheme 4). In general, our reaction conditions were found

to be nicely applicable to substrates bearing various functional groups including alkyl 1b-1c, alkoxy $\mathbf{1 d - 1 e}$, halogen $\mathbf{1 f - 1 h}$, ester $\mathbf{1 i}$ and pyridine analogue $\mathbf{1 j}$. It is noteworthy that unlike $o$ aminophenols, ${ }^{8 f}$ the corresponding $o$-nitrophenols substrates were commercially available and readily obtained by direct nitration of the coresponding phenols.

Finally, we extended our reactions to 2-methylquinoline and analogues $\mathbf{4}$ as stable methyl iminic substrates (Scheme 5). Since they all contain a pyridine ring, their reaction involved DIPEA as the only additive. 2-Methylquinoline 4a was found to be an excellent substrate capable of reacting with a wide range of $o$ nitrophenols $\mathbf{1 a}-\mathbf{1 k}$. Among the resulting products, $\mathbf{5} \mathbf{d a}$ and $\mathbf{5 g a}$, represent the direct precursor or core structure of fluorescent probes $\mathbf{V}$ and IV (Scheme 1). Compared to our previous catalytic system based on metallic iron and sulfur which required high temperature up to $150{ }^{\circ} \mathrm{C}, 14 \mathrm{a}$ the present system using DIPEA as a base and $\mathrm{FeCl}_{2} \bullet 4 \mathrm{H}_{2} \mathrm{O}$ as an iron source showed to be more reactive, allowing the reaction to proceed at only $80 \stackrel{\circ}{ } \mathrm{C}$.
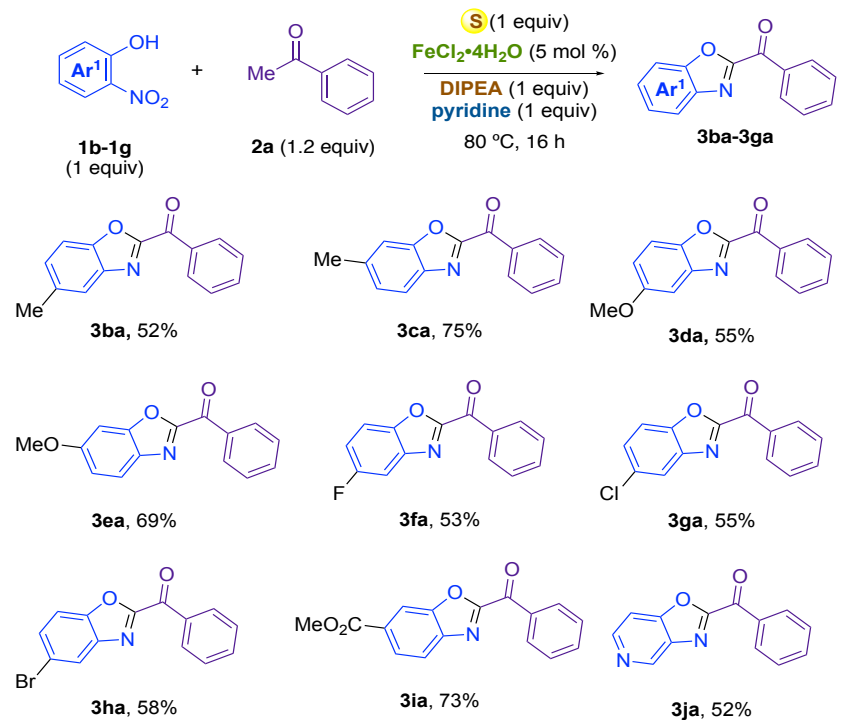

Scheme 4. Scope of $o$-Nitrophenols 1

Other isomer of $\mathbf{4 a}$ bearing an active methyl group such as 4methylquinoline $\mathbf{4 b}$ and 1-methylisoquinoline $\mathbf{4 c}$ were also competent substrates. On the other hand 2-methylquinoxaline $\mathbf{4 d}$ reacted sluggishly under the standard conditions but provide the expected product 5ad, which is a core structure of compound III presented in Scheme 1 as an anti-proliferative compound.

At this stage, although the detailed mechanism was not fully elucidated, we were eager to investigate some control reactions for a better understanding of the reaction pathway.

Since the phenol function was found to complex with $\mathrm{Fe}^{3+}$, we carried out experiments with a range of nitro substrates without an $o$-phenol function such as nitrophenol, $o$ methoxynitrophenol, $p$-nitrophenol with acetophenone $\mathbf{2 a}$ (eq. 1). In all cases tested, the expected redox condensed products were not formed in detectable or significant amounts. This suggests the central role of the $o$-hydroxy group in the reaction, allowing the reaction to occur at a temperature as low as $80^{\circ} \mathrm{C}$. 
Second, our optimized conditions were not applicable to aliphatic methyl ketones such as pinacolone, isopropyl methyl ketone and 2-pentanone (eq. 2). It is strongly possible that the reaction occurs via enol tautomer of the methyl ketone derivative $\mathbf{B}$ and such an intermediate is stabilized more effectively by an aryl group than an alkyl one.

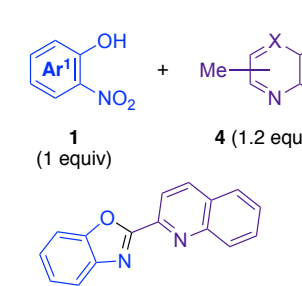

$$
\begin{gathered}
\mathrm{S} \text { (1 equiv) } \\
\underset{\mathrm{FeCl}_{2} \cdot 4 \mathrm{H}_{2} \mathrm{O}(5 \mathrm{~mol} \%)}{\mathrm{DIPEA}(1 \text { equiv) }} \\
80-100^{\circ} \mathrm{C}, 16 \mathrm{~h}
\end{gathered}
$$

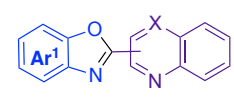

5
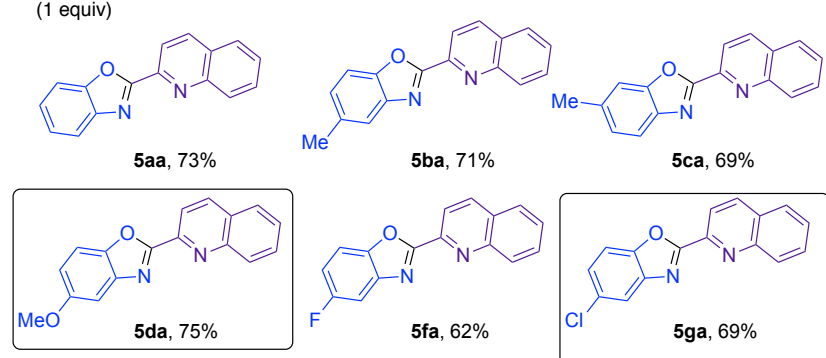

5ba, $71 \%$

5ca, $69 \%$
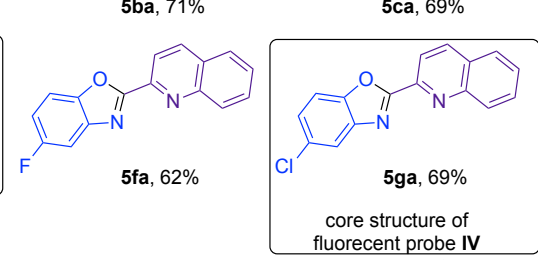

methylated product

fluorecent probe $\mathbf{V}$ uorecent probe IV

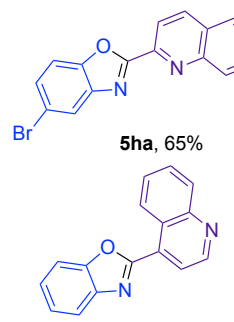

5ab, $75 \%$
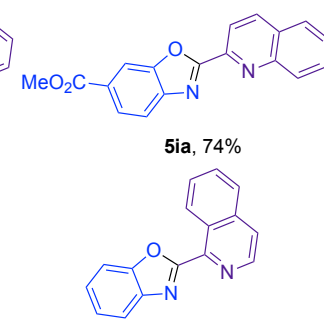

5ac, $55 \%$
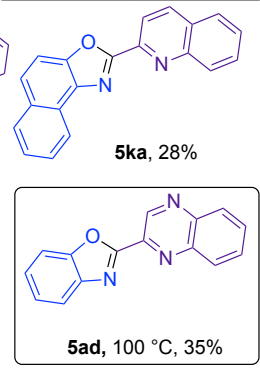

core structure of compound ill with anti-proliferative activity

Scheme 5. Scope of Methylquinolines 4

Third, the redox condensation of $1 \mathbf{a}$ and $2 \mathbf{a}$ failed also when monosubstituted sulfide precursors such as dimethyl, dibenzyl or diphenyl disulfide as well as their thiol parents were used in place of elemental sulfur (eq. 3). It should be noted that, unlike these sulfur derivatives, elemental sulfur is capable of forming $\mathrm{Fe} / \mathrm{S}$ clusters, suggesting the involvement of this kind of catalyst in the reactions.

Based on these observations as well as on our previous experiences on similar redox condensation, we tentatively proposed a reaction mechanism starting with the formation of $\mathrm{Fe} / \mathrm{S}$ clusters $\mathbf{A}$ (in a simplified form without charge on iron atoms for clarity reason) from iron salt and sulfur. Although the exact structures of such catalytic species could not be determined in the reactions mixtures, the key features are that they contain many iron atoms capable of existing in a wide range of easily interchangeable oxidation states. These complexes are stabilized by both sulfur bridges and external sulfide ligands. Complexation of 0 -nitrophenolate and 2mercaptoacetophenone (generated in situ from sulfur and acetophenone $\mathbf{2} \mathbf{a}$ ) with iron to form $\mathbf{B}$ followed by a cascade of intramolecular condensation of the methylene group to the nitro group would lead to nitrone $\mathbf{D}$ via $\mathbf{C}$. Extrusion of benzoyl nitrone $\mathbf{E}$ from $\mathbf{D}$ will regenerate catalyst $\mathbf{A}$. Deoxygenation of $\mathbf{E}$ with $\mathrm{H}_{2} \mathrm{~S}$ will provide the expected product 3aa.
Reaction of 2-nitroaniline with acetophenone resulted in complex mixtures from which we could identify the presence of 2-phenylquinoxaline. Reaction of 2,2'-dinitrodiphenyl disulfide, a stable analogs of 2-nitrothiophenol, with acetophenone could proceed without iron catalyst to provide 2benzoylbenzothiazole. ${ }^{17}$

Control experiments:

$$
\begin{gathered}
\text { unchanged } \\
\text { (eq. 1) }
\end{gathered}
$$

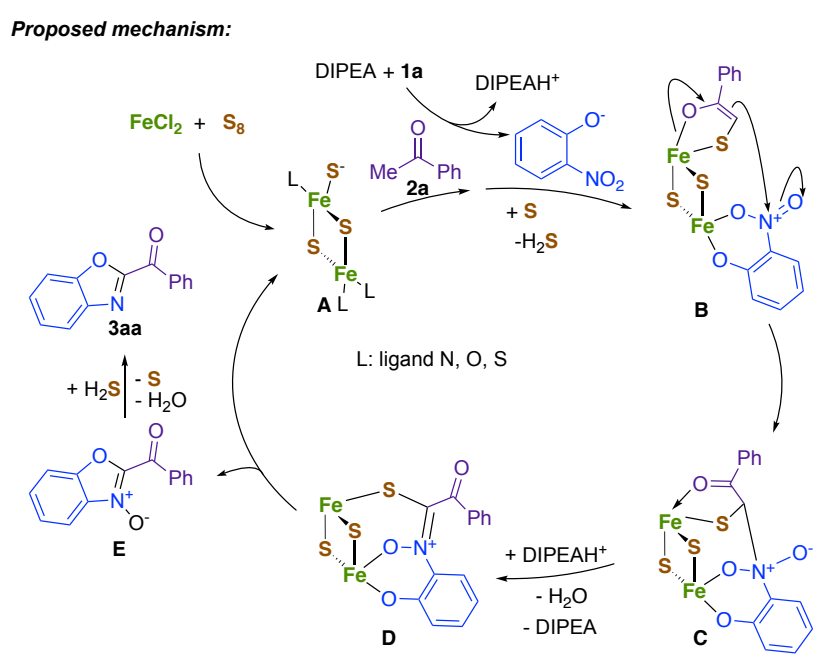

Scheme 6. Control Experiments and Proposed Mechanism

\section{Conclusions}

In conclusion, we have developed a direct access to 2benzoylbenzoxazoles from 2-nitrophenols and acetophenones. Iron sulfur catalysts generated in situ from simple iron salts such as $\mathrm{FeCl}_{2} \bullet 4 \mathrm{H}_{2} \mathrm{O}$ and elemental sulfur $\mathrm{S}_{8}$ were found to be highly reactive, allowing the reactions to proceed at temperatures as low as $80^{\circ} \mathrm{C}$ with high functional group tolerance for both substrates. Moreover, o-nitrophenols, acetophenones and methylquinoline analogues are inexpensive and readily available starting materials with high degree of structural diversity. Compared to known methods, our developed strategy is inarguably the cheapest and most convenient method to provide a library 2-benzoylbenzoxazoles and 2quinolylbenzoxazoles in a green manner since water is the only by-product. We strongly believe that with suitable modifications, the $\mathrm{Fe} / \mathrm{S}$ catalysts will find wider applications 
with temperatures approaching that of physiological conditions. Such efforts are being pursued in our laboratory.

\section{Conflicts of interest}

There are no conflicts to declare.

\section{Acknowledgment}

We thank Institut de Chimie des Substances Naturelles and Institute of Chemistry - Vietnam Academy of Science and Technology (KHCBHH.01/18-20) for financial support.

\section{Notes and references}

1 For a recent review on 2-benzoylbenzoxazoles, see: N. Aljaar, R. Gujjarappa, M. Al-Refai, M. Shtaiwi, C. C. J. Malakar, Heterocyclic Chem., 2019, 56, 2730.

2 (a) M. J. Myllymäki, S. M. Saario, A. O. Kataja, J. A. CastilloMelendez, T. Nevalainen, R. O. Juvonen, T. Järvinen, A. M. P. Koskinen, J. Med. Chem., 2007, 50, 4236; (b) D. L. Boger, H. Miyauchi, M. P. Hedrick, Bioorg. Med. Chem. Lett., 2001, 11, 1517; (c) D. L. Boger, H. Sato, A. E. Lerner, M. P. Hedrick, R. A. Fecik, H. Miyauchi, G. D. Wilkie, B. J. Austin, M. P. Patricelli, B. F. Cravatt, Proc. Natl. Acad. Sci. U. S. A., 2000, 97, 5044.

3 (a) J. Han, X. Tang, Y. Wang, R. Liu, L. Wang and L. Ni, Spectrochim. Acta A., 2018, 205, 597; (b) Q. Wu, M. Mao, W. Liang and F. J. Stadler, Talanta., 2018, 186, 110.

4 (a) X. F. Wu, P. Anbarasan, H. Neumann and M. Beller, Angew. Chem., Int. Ed., 2010, 49, 7316; (b) N. K. Harn, C. J. Gramer and B. A. Anderson, Tetrahedron Lett. 1995, 36, 9453; (c) J. Chen, C.-M. Li, J. Wang, S. Ahn, Z. Wang, Y. Lu, J. T. Dalton, D. D. Miller and W. Li, Bioorg. Med. Chem., 2011, 19, 4782; (d) K. Yang, C. Zhang, P. Wang, Y. Zhang and H. Ge, Chem. - Eur. J., 2014, 20, 7241; (e) P. Lassalas, F. Marsais and C. Hoarau, Synlett, 2013, 24, 2233; (f) W. Jia, Y. Jian, B. Huang, C. Yang and W. Xia, Synlett, 2018, 29, 1881; (g) K. Yang, X. Chen, Y. Wang, W. Li, A. A. Kadi, H. K. Fun, H. Sun, Y. Zhang, G. Li and H. Lu, J. Org. Chem., 2015, 80, 11065; (h) S. Sharma, I. A. Khan and A. K. Saxena, Adv. Synth. Catal., 2013 355, 673; (i) Y. Ogiwara, Y. lino and N. Sakai, Chem. - Eur. J., 2019, 25, 6513; (j) S. Karthik and T. Gandhi, Org. Lett., 2017, 19, 5486; (k) X. Chen, X. Cui, F. Yang and Y. Wu, Org. Lett., 2015, 17, 1445; (I) K. Inamoto, Y. Araki, S. Kikkawa, M. Yonemoto, Y. Tanaka and Y. Kondo, Org. Biomol. Chem., 2013, 11, 4438; (m) F. Derridj, J. Roger, F. Geneste, S. Djebbar and H. Doucet, J. Organomet. Chem., 2009, 694, 455; (n) H. Wang, Y. Pei, J. Bai, J. Zhang, Y. Wu and X. Cui, RSC Adv., 2014, 4, 26244.

5 (a) Q. Y. Toh, A. McNally, S. Vera, N. Erdmann and M. J. Gaunt, J. Am. Chem. Soc., 2013, 135, 3772; (b) Z. Yin, Z. Zhang, J. F. Kadow, N. A. Meanwell and T. Wang, J. Org. Chem., 2004, 69, 1364.

6 (a) H. Sterckx, J. De Houwer, C. Mensch, I. Caretti, K. A. Tehrani, W. A. Herrebout, S. V. Doorslaer and B. U. W. Maes, Chem. Sci., 2016, 7, 346; (b) H. Wang, J. Liu, J. P. Qu and Y. B. Kang, J. Org. Chem., 2020, 85, 3942; (c) J. Kumar, A. Gupta and S. Bhadra, Org. Biomol. Chem. 2019, 17, 3314; (d) W. A. Skinner, F. Gualtiere, G. Brody and A. H. Fieldsteel, J. Med. Chem. 1971, 14, 546.

7 (a) R. Tynebor and E. Millings, Synth. Commun., 2013, 43, 1902; (b) S. M. Anil, K. R. Kiran, K. S. Rangappa, M. P. Sadashiva, J. B. Shruthi, K. P. Sukrutha and T. R. Swaroop,
Synthesis 2019, 51, 4205; (c) L. Zhao, B. Liu, Q. Tan, C. Ding and B. Xu, Org. Lett., 2019, 21, 9223; (d) J. A. Garduño and J. J. García, ACS Catal., 2015, 5, 3470.

8 (a) L. Cui, Y. He and X. Fan, Chin. J. Chem., 2012, 30, 992; (b) X. Fan, Y. He, X. Zhang, S. Guo and Y. Wang, Tetrahedron, 2011, 67, 6369; (c) J. Jiang, H. Zou, Q. Dong, R. Wang, L. Lu, Y. Zhu and W. He, J. Org. Chem., 2016, 81, 51; (d) C. Wu, X. Xin, Z. Fu, L. Xie, K. Liu, Z. Wang, W. Li, Z. Yuan and W. He, Green Chem., 2017, 19, 1983; (e) T. Hisano, M. Ichikawa, K. Tsumoto and M. Tasaki, Chem. Pharm. Bull. 1982, 30, 2996; (f) L. A. Nguyen, Q. A. Ngo, P. Retailleau and T. B. Nguyen, Adv. Synth. Catal., 2021, 363, 2098; (g) T. T. T. Nguyen, L. A. Nguyen, Q. A. Ngo, M. Koleski and T. B. Nguyen, Org. Chem. Front., 2021, 8, 1593.

9 (a) S. S. K. Boominathan, W.-P. Hu, G. C. Senadi, J. K. Vandavasi and J.-J. Wang, Chem. Commun., 2014, 50, 6726; (b) Baranovsky, V. Ilia Konstantinova, S. Lidia Tolmachev, A. Mikhail Popov, V. Vadim Lyssenko, A. Konstantin and Rakitin, A. Oleg, Molecules, 2020, 25, 3768. For an example of oxidative cyclization, see: (c) K. G. Ozokan, M. K. Gumus and S. Kaban, J. Heterocycl. Chem., 2008, 45, 1831.

10 N. Aljaar, C. C. Malakar, J. Conrad and U. Beifuss, J. Org. Chem., 2015, 80, 10829.

11 R. R. Crichton, Iron: essential for almost all life, in Biological Inorganic Chemistry: An Introduction, R.R. Crichton Ed.), Elsevier, 2008, 381.

12 D. C. Johnson, D. R. Dean, A. D. Smith and M. K. Johnson, Annu. Rev. Biochem., 2005, 74, 247.

13 H. Beinert, R. H. Holm and E. Munck, Science, 1997, 277, 653.

14 (a) T. B. Nguyen, L. Ermolenko, A. Almourabit, J. Am. Chem. Soc. 2013, 135, 118; (b) T. B. Nguyen, P. Retailleau, A. Almourabit, Org. Lett. 2013, 15, 5238; (c) T. B. Nguyen, J. Le Bescont, L. Ermolenko, A. Almourabit, Org. Lett. 2013, 15, 6218; d) T. B. Nguyen, L. Ermolenko, M. Corbin, A. Almourabit, Org. Chem. Front. 2014, 1, 1157; (e) T. B. Nguyen, L. Ermolenko, A. Almourabit, Synthesis 2015, 47, 1741; (f) T. B. Nguyen, J. Cheung-Lung, Eur. J. Org. Chem. 2018, 5815 .

15 (a) H. Gan, Chem. Select 2020, 5, 717; (b) M. Saibara, K. Ashida, K. Satomi, T. Iwai, T. Nakai, M. Mihara, T. Ito, T. Mizuno, Synlett 2014, 25, 1565; (c) M. Saibara, K. Ashida, T. Mizuno, T. Ito, M. Mihara, T. Iwai, T. Nakai, TW2016/7934, 2016, A; (d) M. Saibara, K. Ashida, T. Mizuno, T. Ito, M. Mihara, T. Iwai, T. Nakai, JP2015/107934, 2015, A; (e) Y. Shao, Z. Guo, H. Li, Y. Su, X. Wang, Angew. Chem. Int. Ed. 2017, 56, 3226.

16 For recent reviews on the use of sulfur in organic synthesis, see: (a) T. B. Nguyen, Adv. Synth. Catal. 2017, 359, 1106; (b) T. B. Nguyen, Asian J. Org. Chem. 2017, 6, 477; (c) T. B. Nguyen, Adv. Synth. Catal. 2020, 362, 3448. For selected works on the use of sulfur in organic synthesis, see: (d) M. Wang, Z. Dai and X. Jiang, Nat. Commun., 2019, 10, 2661; (e) M. Wang, Q. Fan and X. Jiang, Org. Lett., 2016, 18, 5756; (f) T. B. Nguyen, L. Ermolenko, W. A. Dean and A. Al-Mourabit, Org. Lett., 2012, 14, 5948; (g) T. B. Nguyen, M. Q. Tran, L. Ermolenko and Ali Al-Mourabit, Org. Lett., 2014, 16, 310.

17 T. B. Nguyen, K. Pasturaud, L. Ermolenko and A. Almourabit, Org. Lett., 2015, 17, 2562. 